\title{
Komposisi Ekstrak Stevia (Stevia rebaudiana) Terhadap Karakteristik Sirup Bit (Beta vulgaris L.)
}

\section{The Composition of Stevia (Stevia rebaudiana) Extract on The Characteristic Beet (Beta vulgaris L.) Syrup}

\section{Elvi Fitriani Simarmata, Maria Marina Herawati, Alfred Jansen Sutrisno, Yoga Aji Handoko*}

\author{
${ }^{1}$ Program Studi Agroteknologi Fakultas Pertanian dan Bisnis Universitas Kristen Satya \\ Wacana \\ *E-mail: yoga.handoko@staff.uksw.edu
}

\begin{abstract}
Beetroots are a type of tubers with a distinctive purplish-red color and are beneficial for health with a high amount of betacyanin as an antioxidan. But the beetroot is less liked by the public because of the strong enough earthy taste, so it is necessary to do new innovations for the product to be accepted by the community, one of which is the functional beet syrup drink. To create a preferred flavor, the addition of other food additives and sweetener stevia which has a sweetness level of 200-300 times that of sugar and includes non-calorie sweeteners is done. This study aims to analyze the best concentration of stevia extract on the sweetness level and beetroot characteristics and determine the level of panelists' preference for beetroot syrup (Beta vulgaris L.) with organoleptic tests. This research was conducted with a randomized block design (RBD), the data were analyzed by variance (ANOVA), if the data obtained were significantly different, the DMRT would be further tested at $5 \%$ level. The highest betacyanin was in the SBS15 treatment $(31.74 \mathrm{mg} / \mathrm{l})$, the highest total dissolved solids was in the SBS treatment $\left(3.25^{\circ}\right.$ Brix), the highest $p H$ was in the SBS15 treatment (4.22), the highest vitamin $C$ was in the SBS15 treatment (11.66 $\mathrm{mg}$ ascorbic acid / $10 \mathrm{ml}$ ). Organoleptic results beet syrup with the addition of stevia extract of $6 \%$ was the most preferred sample by panelists.
\end{abstract}

Keywords: beetroot,betacyanin, organoleptic, stevia, syrup,

Disubmit :10 Agustus 2019 ; Diterima: 20 November 2019; Disetujui: 08 Desember 2019

\section{PENDAHULUAN}

Bit merupakan jenis umbi-umbian dengan warna khas umbi yaitu merah keunguan. Umbi bit mengandung banyak manfaat kesehatan karena mengandung banyak gizi diantaranya: karbohidrat, vitamin dan lemak. Selain itu, bit mengandung vitamin B, vitamin A, dan vitamin C (Puslitbangkes, 2013). Bit juga mengandung betasianin yaitu pigmen yang biasa digunakan sebagai pewarna makanan, Betasianin juga memiliki manfaat sebagai antioksidan yang cukup tinggi serta berguna dalam pencegahan infeksi. Namun dibalik manfaat dari umbi bit tersebut, banyak masyarakat yang tidak menyukai umbi bit (Riskesdas, 2010), karena rasa umbi bit yang kurang enak dan aroma tanah yang kuat saat dikonsumsi (Juniaty et al, 2015). Untuk meningkatkan kesukaan masyarakat terhadap umbi bit perlu dilakukan inovasi olahan baru terhadap umbi bit. Beberapa olahan bit yang telah ditemui yaitu jus buah bit dan permen jeli (Hanifan et al, 2016). Namun demikian, perlu dikembangkan produk pengolahan bit lainnya yang belum banyak dilakukan yaitu 
pengolahan bit sebagai sirup, dimana sirup merupakan salah satu produk minuman yang praktis dan telah banyak disukai oleh masyarakat.

Beberapa pemanis yang digunakan dalam pembuatan sirup yaitu gula yang memiliki kegunaan dalam pembentukan karakteristik sirup (Fitri et al, 2017), kemudian madu yang pada umumnya memiliki manfaat dalam hal penambah energi bagi tubuh (Yuliana et al, 2017). Tetapi penggunaan gula dan madu pada produk minuman memiliki kalori yang lebih tinggi yaitu sebesar 364 kkal (Darwin, 2013), sehingga perlu dilakukan inovasi baru sirup dengan penambahan pemanis non kalori yaitu stevia. Stevia dapat menghasilkan rasa manis 200-300 kali rasa manis dari tanaman tebu (Geuns, 2003) dan juga memiliki manfaat, diantaranya diet kalori bagi penderita diabetes. Inovasi sirup bit dengan pemanis stevia juga dapat memberikan nilai tambah gizi, rasa, maupun aroma dengan pemberian jeruk nipis yang diharapkan dapat diterima konsumen. Selain stevia, penambahan jeruk nipis dalam sirup bit ini bermanfaat dalam penurunan kadar kolesterol dalam darah karena mengandung pectin, saponins, tanins alkaloids, streroid syneprine dan flavonoids (Aktar, 2013).

Berdasarkan uraian diatas maka perlu dilakukan penelitian pengembangan produk olahan umbi bit menjadi sirup bit sebagai minuman fungsional yang dapat diterima oleh konsumen namun tetap menjaga bahkan menaikkan nilai gizi. Penelitian ini bertujuan untuk menganalisis konsentrasi ekstrak stevia terhadap karakteristik sirup bit serta menentukan tingkat kualitas organoleptik sirup bit.

\section{METODE PENELITIAN}

Bahan utama dari penelitian ini adalah umbi bit (Beta vulgaris L.) varietas ayumi 04 berumur 45 hari setelah tanam yang diproduksi di Desa Sumberejo, Kecamatan Ngablak, Kabupaten Magelang, Jawa Tengah. Bahan tambahan yaitu stevia, jeruk nipis, air mineral, $\mathrm{CMC}$, sedangkan bahan kimia yang digunakan yaitu aquadest, amilum $1 \%$, iodin (I2) $0,1 \mathrm{~N}, \mathrm{pH}$ buffer 1 , dan $\mathrm{pH}$ buffer 4,5. Alat yang digunakan dalam pembuatan sirup bit yaitu pisau, juicer (merk Philips), saringan, panci, wadah, beakerglass, hot plate, timbangan digital, sendok, kompor gas, termometer, botol sirup, talenan, corong. Sedangkan alat yang digunakan untuk analisis produk minuman sirup bit yaitu pH meter (Hi 9812-5), spektrofotometer (Shimadzu UV-Vis Mini 1240), hand refractometer (Atago N1), erlenmeyer, buret, statif, kuvet, tabung reaksi, rak tabung reaksi, pilius, pipet ukur.

Analisis yang digunakan yaitu Rancangan Acak Kelompok (RAK) dengan 4 ulangan. Perlakuan yang dilakukan dalam pembuatan sirup bit yaitu sari umbi bit + ekstrak stevia SBS (sari umbi bit + 0\% ); SBS3 (sari umbi bit $+3 \%$ ); SBS6 (sari umbi bit $+6 \%$ ); SBS9 (sari umbi bit $+9 \%$ ); SBS12 (sari umbi bit $+12 \%$ ); SBS15 (sari umbi bit $+15 \%$ ). Untuk mengetahui pengaruh perlakuan, data dianalisis sidik ragam galat dan uji signifikansi. Apabila pada perlakuan terdapat pengaruh nyata, maka data akan dianalisis lebih lanjut menggunakan uji lanjut Duncan's Multiple Range Test (DMRT) pada taraf 5\%.

Pembuatan sirup bit diawali dengan pencucian umbi bit, pengupasan kulit, pemotongan umbi dan mengambil sari umbi bit dengan menggunakan alat juicer. Tahapan selanjutnya yaitu: dilakukan penambahan sari jeruk nipis $10 \%$ pada sari umbi dan dilakukan blanching dengan suhu $60^{\circ} \mathrm{C}$ selama 3 menit, setelah itu penambahan CMC 1\%. Kemudian sari umbi tersebut ditambah ekstrak stevia pada tiap perlakuan secara terpisah dengan konsentrasi 3\%, 6\%, 9\%, 12\%, 15\%. Kemudian sari umbi bit tersebut diaduk hingga rata, dimasukkan dalam botol bersih, lalu dilakukan pengukuran $\mathrm{pH}$, total padatan terlarut, kandungan betasianin, kandungan vitamin $\mathrm{C}$, serta uji organoleptik yang meliputi: warna, aroma dan rasa.

\section{HASIL DAN PEMBAHASAN}

Penelitian terkait konsentrasi ekstrak stevia terhadap karakteristik sirup bit dan kualitas organoleptiknya diperoleh hasil sebagai berikut:

Total padatan terlarut. Hasil analisis sidik ragam menunjukkan adanya pengaruh sangat nyata terhadap total padatan terlarut yang ditunjukkan melalui Tabel 1. 
Simarmata, dkk: Komposisi Ekstrak Stevia (Stevia rebaudiana) Terhadap Karakteristik Sirup Bit .......

Tabel 1. Hasil uji DMRT terhadap total padatan terlarut sirup bit

\begin{tabular}{ll}
\hline Perlakuan & Padatan terlarut \\
\hline SBS & $3,25 \mathrm{a}$ \\
SBS3 & $1,65 \mathrm{e}$ \\
SBS6 & $2 \mathrm{~d}$ \\
SBS9 & $2,4 \mathrm{c}$ \\
SBS12 & $2,9 \mathrm{~b}$ \\
SBS15 & $3,2 \mathrm{a}$ \\
\hline
\end{tabular}

Keterangan: Setiap huruf yang berbeda menunjukkan adanya perbedaan yang nyata pada taraf 5\% Uji Duncan SBS: kontrol, SBS3: penambahan ekstrak stevia 3\%, SBS6: penambahan ekstrak stevia 6\%, SBS9 penambahan ekstrak stevia 9\%, SBS12: penambahan ekstrak stevia 12\%, SBS15: penambahan ekstrak stevia $15 \%$.

Total padatan terlarut pada sirup bit dinyatakan dalam ${ }^{\circ}$ Brix dan total padatan terlarut menunjukkan kandungan bahan-bahan yang terlarut dalam sebuah larutan. Berdasarkan Tabel 1, hasil analisis sidik ragam menunjukkan bahwa penambahan ekstrak stevia terhadap sirup bit dengan konsentrasi yang berbeda memberikan pengaruh yang sangat berbeda nyata $(p>0,01)$ terhadap total padatan terlarut. Tabel 1 juga memperlihatkan bahwa semakin tinggi konsentrasi ekstrak stevia yang digunakan, maka semakin tinggi total padatan terlarut yang terjadi mulai dari penambahan ekstrak stevia 3\%. Nilai padatan terlarut paling tinggi ada pada perlakuan SBS tanpa penambahan ekstrak stevia yaitu 3,25 ${ }^{\circ}$ Brix dan terendah ada pada penambahan ekstrak stevia $3 \%$ yaitu $1,65{ }^{\circ}$ Brix. Tingginya padatan terlarut pada perlakuan kontrol dikarenakan oleh CMC dan jeruk nipis, dimana CMC memiliki kemampuan dalam mengikat air, asam-asam organik serta komponen lainnya sehingga akan lebih stabil jika komponen-komponen lain, seperti air serta asam-asam organik terikat dengan baik dan akan meningkatkan padatan terlarut (Sulastri, 2008). Jeruk nipis juga memiliki padatan terlarut sebesar $30,75^{\circ}$ Brix yang berperan juga dalam peningkatan padatan terlarut (Evana, 2007), oleh karena itu terjadi peningkatan padatan terlarut pada perlakuan kontrol Menurut (Wijaya \& Prawira, 2002), penyebab dari peningkatan total padatan terlarut yaitu komponen-komponen komplek seperti karbohidrat yang larut sehingga kenaikan total padatan terlarut terjadi. Dimana stevia juga mengandung karbohidrat yaitu sebanyak 35,2-61,9 g/ $100 \mathrm{~g}$ bahan (Abou-Arab et al, 2010). Berdasarkan pernyataan tersebut dapat dilihat bahwa seiring penambahan ekstrak stevia mulai dari $3 \%$ akan meningkat juga padatan terlarutnya yang disebabkan meningkatnya karbohidrat yang terurai seiring penambahan konsentrasi ekstrak stevia. Pada sisi yang lain, makin tingginya nilai padatan terlarut juga terkait dengan kelarutan stevia pada senyawa polar, seperti air (Abou-Arab et al., 2010). Meningkatnya total padatan terlarut disebabkan oleh air bebas yang diikat oleh bahan penstabil. Oleh karena itu, konsentrasi bahan yang larut akan meningkat. Semakin meningkatnya konsentrasi bahan atau semakin banyak bahan yang digunakan, maka semakin banyak juga partikel yang diikat oleh bahan penstabil dan total padatan terlarut akan meningkat (Farikha et al, 2013).

pH. Hasil analisis sidik ragam menunjukkan adanya pengaruh nyata nilai $\mathrm{pH}$ dalam berbagai perlakuan (Tabel 2). $\mathrm{pH}$ akan naik setiap penambahan ekstrak stevia, dimana $\mathrm{pH}$ tertinggi ada pada perlakuan penambahan ekstrak stevia 15\% SBS15. Pengukuran $\mathrm{pH}$ juga penting dilakukan, karena nilai $\mathrm{pH}$ yang stabil dari larutan menunjukkan bahwa distribusi bahan dasar dalam sediaan merata. Dimana nilai $\mathrm{pH}$ itu sendiri dihubungkan dengan kualitas suatu produk yang berkaitan dengan pengawetan maupun pengolahan bahan makanan. 
Jurnal Penelitian Pertanian Terapan

Tabel 2. Hasil uji DMRT terhadap pH sirup bit

\begin{tabular}{ll}
\hline Perlakuan & $\mathrm{pH}$ \\
\hline SBS & $3,97 \mathrm{~d}$ \\
SBS3 & $4,05 \mathrm{c}$ \\
\hline SBS6 & $4,12 \mathrm{~b}$ \\
SBS9 & $4,17 \mathrm{ab}$ \\
SBS12 & $4,2 \mathrm{ab}$ \\
SBS15 & $4,22 \mathrm{a}$ \\
\hline
\end{tabular}

Keterangan:Setiap huruf yang berbeda menunjukkan adanya perbedaan yang nyata pada taraf 5\% Uji Duncan SBS: kontrol, SBS3: penambahan ekstrak stevia 3\%, SBS6: penambahan ekstrak stevia 6\%, SBS9: penambahan ekstrak stevia 9\%, SBS12: penambahan ekstrak stevia 12\%, SBS15: penambahan ekstrak stevia $15 \%$

Berdasarkan nilai $\mathrm{pH}$, bahan pangan dapat dikelompokkan dalam beberapa kategori, yaitu pangan berasam rendah $(\mathrm{pH}>5,3)$, sedang $(\mathrm{pH} 4,5-5,3)$, asam $(\mathrm{pH} 3,7-4,5)$, tinggi $(\mathrm{pH}<3,7)$ (Rienoviar \& Nashrianto, 2010). Semakin rendah nilai pH, maka derajat keasaman dari larutan tersebut akan semakin tinggi (Fardiaz, 1998). pH sirup bit berkisar antara 3,97-4,22 yang berarti sirup bit dikelompokkan pada produk pangan yang memiliki $\mathrm{pH}$ asam. Pada masing-masing perlakuan derajat keasaman semakin meningkat seiring penambahan ekstrak stevia, hal ini dikarenakan ekstrak stevia memiliki pH yang lebih tinggi dibandingkan $\mathrm{pH}$ jeruk nipis. Dimana $\mathrm{pH}$ dari jeruk nipis yaitu 2,17 (Ermawati, 2008) dan pH pada ekstrak stevia berkisar antara 5-6, sehingga semakin banyak ekstrak stevia yang diberikan akan meningkatkan nilai $\mathrm{pH}$. Pada penelitian ini nilai $\mathrm{pH}$ yang memenuhi persyaratan Standar Nasional Indonesia Sirup ada pada perlakuan SBS dan SBS3 yaitu 3,5-4,0 (BSN, 1992).

Kandungan betasianin. Hasil dari analisis sidik ragam menunjukkan adanya pengaruh sangat nyata terhadap kandungan betasianin ditampilkan dalam Tabel 3.

Tabel 3. Hasil uji DMRT terhadap kandungan betasianin sirup bit

\begin{tabular}{ll}
\hline Perlakuan & Betasianin $(\mathrm{mg} / \mathrm{l})$ \\
\hline SBS & $2,29 \mathrm{f}$ \\
SBS3 & $8,71 \mathrm{e}$ \\
SBS6 & $11,11 \mathrm{~d}$ \\
SBS9 & $15,58 \mathrm{c}$ \\
SBS12 & $27,61 \mathrm{~b}$ \\
SBS15 & $31,74 \mathrm{a}$ \\
\hline
\end{tabular}

Keterangan:Setiap huruf yang berbeda menunjukkan adanya perbedaan yang nyata pada taraf 5\% Uji Duncan SBS: kontrol, SBS3: penambahan ekstrak stevia 3\%, SBS6: penambahan ekstrak stevia 6\%, SBS9: penambahan ekstrak stevia 9\%, SBS12: penambahan ekstrak stevia 12\%, SBS15: penambahan ekstrak stevia $15 \%$

Betasianin merupakan pigmen utama yang terdapat pada umbi bit merah dan diketahui mengandung antioksidan tinggi (Mastuti, 2010), yang diperlukan oleh tubuh untuk menetralisir radikal bebas dan mencegah kerusakan akibat radikal bebas (Escribano et al, 1998). Betasianin juga dapat digunakan sebagai pewarna alami (Stintzing \& Carle, 2004). Analianasari \& Apriyani, ( 2018) menggunakan kulit buah naga merah yang mengandung betasinin sebagai pewarna alami pada frozen yogurt. Pengukuran betasianin dilakukan dengan tujuan mendapatkan pengukuran seberapa besar kandungan betasianin yang terkandung pada sirup bit setelah ditambahkan bahan pangan lain. 
Tabel 3 menunjukkan bahwa formulasi sirup bit yang menggunakan pemanis ekstrak stevia, kandungan betasianinnya meningkat seiring dengan peningkatan konsentrasi ekstrak stevia. Kandungan betasianin tertinggi pada sirup bit yaitu $31,74 \mathrm{mg} / \mathrm{l}$ ada pada perlakuan penambahan konsentrasi ekstrak stevia $15 \%$. Faktor yang mempengaruhi betasianin diantaranya yaitu suhu dan $\mathrm{pH}$, yang relatif stabil pada pH 3-7 (Jackman, R \& J, 1996), sedangkan tingkat kestabilan betasianin akan menurun pada suhu 70 dan 80 ${ }^{\circ} \mathrm{C}$ (Havlikova, L \& Mikova, 1983). Kandungan betasiainin pada sirup bit ini terus meningkat dikarenakan pH yang dihasilkan ataupun suhu yang digunakan masih termasuk dalam faktor yang mempengaruhi agar betasianin tidak rusak melainkan dapat mempertahankan kandungan betasianin dari sirup bit. Daun stevia yang telah diekstrak akan membentuk agregat dari campuran reaksi (Kinghorn, 2002), dimana stevia dapat ditambahkan pada produk makanan dengan berbagai perlakuan tanpa ada efek pada produk (Kroyer, 2010). Bit merupakan satu-satunya bahan dalam pembuatan sirup bit yang memiliki kandungan betasianin, sehingga tidak memungkinkan untuk terjadinya penambahan betasianin dari bahan lain yang digunakan. Semakin meningkat jumlah ekstrak stevia yang ditambahkan akan meningkatkan jumlah agregat yang dihasilkan, maka akan memungkinkan terjadinya agregasi pada sirup bit yang ditambahkan pemanis dari ekstrak stevia. Agregasi yang terjadi tersebut yaitu nilai hasil analisis kandungan betasianin menunjukkan data yang seakanakan terjadi peningkatan pada kandungan betasianin.

Kandungan vitamin C. Hasil dari analisis sidik ragam juga menunjukkan adanya pengaruh sangat nyata terhadap kandungan vitamin $\mathrm{C}$ yang ditunjukkan dalam Tabel 4.

Tabel 4. Hasil uji DMRT terhadap Vitamin C sirup bit

\begin{tabular}{ll}
\hline Perlakuan & Vitamin C \\
\hline SBS & $5,94 \mathrm{e}$ \\
SBS3 & $6,82 \mathrm{e}$ \\
SBS6 & $7,92 \mathrm{~d}$ \\
SBS9 & $9,02 \mathrm{c}$ \\
SBS12 & $10,34 \mathrm{~b}$ \\
SBS15 & $11,66 \mathrm{a}$ \\
\hline
\end{tabular}

Keterangan:Setiap huruf yang berbeda menunjukkan adanya perbedaan yang nyata pada taraf 5\% Uji Duncan SBS: kontrol, SBS3: penambahan ekstrak stevia 3\%, SBS6: penambahan ekstrak stevia 6\%, SBS9: penambahan ekstrak stevia 9\%, SBS12: penambahan ekstrak stevia 12\%, SBS15: penambahan ekstrak stevia $15 \%$

Berdasarkan Tabel 4, semakin banyak penambahan ekstrak stevia dalam pembuatan sirup bit akan menaikkan kandungan vitamin $\mathrm{C}$ sirup bit yang dihasilkan. Hasil rata-rata kandungan vitamin $\mathrm{C}$ sirup bit pada Tabel 4. menunjukkan bahwa penambahan ekstrak stevia akan menaikkan nilai kandungan vitamin $\mathrm{C}$ pada sirup bit dengan nilai kandungan vitamin $\mathrm{C}$ tertinggi ada pada penambahan ekstrak stevia pada konsentrasi 15\% (SBS15) yang nilai vitamin C-nya sebesar 11,66 mg asam askorbat/10 ml sirup bit. Kenaikan kandungan vitamin $\mathrm{C}$ disebabkan karena didalam umbi bit memiliki kandungan vitamin $\mathrm{C}$ sebesar $4,90 \mathrm{mg} / 100 \mathrm{~g}$ bahan (USDA, 2014). Selain itu pada stevia juga mengandung banyak vitamin yang salah satunya adalah vitamin C (Elkins, 1997). Vitamin C yang terdapat pada stevia yaitu 14,98 mg/ $100 \mathrm{~g}$ bahan) (Kim et al,. 2011), kemudian jeruk nipis juga berperan dalam meningkatnya kadar vitamin C, dimana jeruk nipis memiliki kandungan vitamin C sebesar 40,0 mg/ $100 \mathrm{~g}$ bahan (Aak, 1994), maka dari itu akan ada peningkatan nilai vitamin $\mathrm{C}$ seiring bertambahnya konsentrasi ekstrak stevia dan ditambah dengan vitamin $\mathrm{C}$ yang terdapat pada umbi bit.

Organoleptik. Hasil dari analisis sidik ragam uji organoletik terhadap sirub bit ditampilkan melalui Tabel 5 . 
Jurnal Penelitian Pertanian Terapan

Tabel 5. Hasil uji DMRT terhadap uji organoleptik pada sirup bit

\begin{tabular}{llll}
\hline \multicolumn{1}{c}{ Perlakuan } & Warna & Aroma & Rasa \\
\hline SBS & $4,2 \mathrm{a}$ & $2,5 \mathrm{c}$ & $1,9 \mathrm{c}$ \\
SBS3 & $4 \mathrm{ab}$ & $2,9 \mathrm{abc}$ & $3,1 \mathrm{a}$ \\
SBS6 & $4 \mathrm{ab}$ & $3,2 \mathrm{a}$ & $3,3 \mathrm{a}$ \\
SBS9 & $4 \mathrm{ab}$ & $3 \mathrm{ab}$ & $2,9 \mathrm{a}$ \\
SBS12 & $3,9 \mathrm{~b}$ & $2,8 \mathrm{abc}$ & $2,3 \mathrm{~b}$ \\
SBS15 & $4 \mathrm{ab}$ & $2,8 \mathrm{bc}$ & $2,1 \mathrm{bc}$ \\
\hline
\end{tabular}

Keterangan:Setiap huruf yang berbeda menunjukkan adanya perbedaan yang nyata pada taraf $5 \%$ Uji Duncan SBS: kontrol, SBS3: penambahan ekstrak stevia 3\%, SBS6: penambahan ekstrak stevia 6\%, SBS9: penambahan ekstrak stevia 9\%, SBS12: penambahan ekstrak stevia 12\%, SBS15: penambahan ekstrak stevia $15 \%$

Warna. Warna merupakan salah satu hal yang pertama dilihat oleh panelis, juga merupakan kriteria umum yang dapat menentukan suatu produk diterima atau tidak oleh konsumen. Secara visual yang akan tampil terlebih dahulu adalah faktor warna yang dapat disebut juga sebagai pengaruh dalam penilaian panelis (Winarno, 2002). Warna menarik merupakan salah satu faktor penentu untuk konsumen mengonsumsi makanan atau minuman (Astuti, 2016). Warna yang dihasilkan oleh sirup bit dengan penambahan ekstrak stevia yaitu merah pekat dan akan jadi merah tua seiring penambahan ekstrak stevia, namun setelah sirup diencerkan dengan air akan menghasilkan warna merah.

Tabel 5 dapat dilihat bahwa kesukaan panelis terhadap warna sirup bit tidak terlalu berbeda jauh, yaitu dari kisaran 3,9 sampai 4,2. Warna sirup yang paling disukai ada pada perlakuan kontrol (SBS). Hal tersebut dikarenakan pada perlakuan kontrol (SBS) tidak dicampur dengan ekstrak stevia menghasilkan warna yang menarik yaitu warna merah pekat. Ekstrak stevia memiliki warna kecoklatan dan warna semakin coklat tua seiring penambahan konsentrasi ekstrak stevia. Sirup bit dengan penambahan ekstrak stevia akan memiliki warna lebih tua seiring penambahan konsentrasinya. Tetapi pada penelitian ini perbedaan warna tidak terlalu berpengaruh nyata, yang berarti sari umbi bit yang dijadikan sirup bit masih mempertahankan pigmen betasianin umbi bit tersebut. Pigmen betasianin merupakan pigmen yang berpengaruh dalam menentukan warna dari sari umbi bit (Chasparinda et al,. 2014).

Aroma. Aroma merupakan hal penting dalam penilaian suatu produk olahan pangan karena dapat memberikan penilaian cepat terhadap penerimaan produk tersebut di konsumen. (Soekarno, 1985) menyatakan bahwa aroma menjadi daya tarik tersendiri dalam banyak hal di dalam menentukan rasa enak dari suatu produk olahan pangan.

Berdasarkan Tabel 5 dapat dilihat bahwa kesukaan panelis terhadap aroma dengan penambahan ekstrak stevia sebesar 3\% sampai pada $15 \%$ berpengaruh nyata dengan kontrol (SBS). Hal tersebut dikarenakan aroma tanah pada sirup bit akan berkurang dan akan muncul bau seperti daun kering dari ekstrak stevia seiring dengan penambahan ekstrak stevia, dimana sirup bit pada perlakuan kontrol tanpa penambahan ekstrak stevia masih menghasilkan bau tanah dari umbi bit itu sendiri dan bau tersebut tidak disukai oleh panelis. Aroma tanah tersebut disebabkan oleh adanya senyawa geosmin yang terdapat pada umbi bit (Lu et al,. 2003). Pada pembentukan aroma sirup bit ini, jeruk nipis juga berperan dalam menghilangkan sedikit bau tanah pada sari umbi bit, karena jeruk nipis juga berfungsi sebagai penyegar dan pewangi, sehingga banyak digunakan sebagai bahan minuman (Sarwono, 2008).

Rasa. Rasa merupakan hal penting dalam penentuan kesukaan panelis terhadap produk pangan itu sendiri. Faktor yang mempengaruhi rasa antara lain suhu, konsentrasi, senyawa kimia dan interaksi dengan komponen rasa selanjutnya (Winarno, 2002). Rasa sirup bit yang dihasilkan merupakan campuran dari sari umbi bit, ekstrak stevia, sari jeruk nipis dan CMC.

Berdasarkan Tabel 5 diatas, perlakuanpenambahan ekstrak stevia sebesar 3\%, 6\%, 9\%, 12\%, 15\% berpengaruh nyata terhadap perlakuan SBS. Dari semua perlakuan dapat dilihat bahwa perlakuan SBS6 
dengan penambahan ekstrak stevia $6 \%$ memiliki tingkat kesukaan paling tinggi dengan skor 3,3. Hal tersebut dikarenakan dengan penambahan ekstrak stevia pada $6 \%$ menghasilkan rasa manis yang pas untuk panelis, dimana pada konsentrasi tersebut sirup tidak terlalu manis atau tidak terlalu hambar. Tetapi kelemahan dari ekstrak stevia yaitu rasa pahit yang terasa setelah mengonsumsi ekstrak daun stevia. Rasa pahit yang muncul disebabkan oleh kandungan minyak, tanin dan flavonoid (Bawane, 2012). Pada penambahan konsentrasi ekstrak stevia sebesar $9-15 \%$ menurunkan nilai kesukaan panelis, karena rasa sirup dengan makin bertambahnya konsentrasi ekstrak stevia, rasa pahit setelah sirup dikonsumsi akan semakin terasa dibandingkan dengan penambahan ekstrak stevia pada konsentrasi 3\% dan 6\%. Seperti yang dinyatakan oleh (Jakinovich \& Moon, 1990), bahwa komponen manis dari stevioside dapat terdeteksi pada konsentrasi rendah yaitu $24 \mathrm{mg} / \mathrm{ml}$.

\section{KESIMPULAN}

Penambahan ekstrak stevia pada sirup bit berpengaruh pada karakteristik maupun organoleptiknya. Total padatan terlarut tertinggi terjadi pada kontrol yaitu $3,25^{\circ} \mathrm{Brix}$; $\mathrm{pH}$ pada sirup bit makin naik seiring penambahan ekstrak stevia yaitu antara 3,97 sampai 4,22; kandungan betasianin tertinggi terjadi pada perlakuan penambahan ekstrak stevia sebesar $15 \%$ yaitu $31,74 \mathrm{mg} / \mathrm{l}$; demikian juga vitamin $\mathrm{C}$ juga naik seiring penambahan ekstrak stevia dan tertinggi ditunjukkan pada perlakuan penambahan ekstrak stevia sebesar 15\% yaitu 11,66 mg asam askorbat. Pada uji organoleptik, warna tidak terlalu berpengaruh terhadap tingkat kesukaan panelis. Penilaian kesukaan tertinggi oleh panelis terhadap aroma dan rasa sirup bit ditunjukkan pada perlakuan penambahan ekstrak stevia sebesar 6\%.

\section{DAFTAR PUSTAKA}

Aak 1994. Budidaya Tanaman Jeruk. Yogyakarta: Kanisius.

Abou-Arab, A., Abou-Arab, A.. \& Abou-Salem, F.. 2010. Physico-Chemical Asessment of Natural

Sweeteners Steviosides Produced from Stevia rebaudiana Bertoni Plant. Afric. J. Food Sci, 4: 269-280.

Analianasari, A. \& Apriyani, M. 2018. Characteristics of Frozen Yoghurt Enriched with Red Dragon Fruit Skin Extracts (Hylocereus polyrhizus). Journal of Physics: Conference Series, 953(1).

Badan Standardisasi Nasional 1992. Cara Uji Makanan dan Minuman. SNI 01-2891-1992.

Bawane 2012. An Overview on Stevia: A Natural Calorie Free Sweetener. International Jurnal of Advantages in Pharmacy, Biology and Chemistry, IJAPBC, 3: 2277-4688.

Chasparinda, E, M., Andriani, M.M. \& Kawiji 2014. Pengaruh Penambahan Jahe (Zingerber offcinalle R) terhadap Karakteristik Fisikokimia dan Organoleptik Sari Buah Bit (Beta vulgaris L.). J. Teknosains Pangan 3, 2: 20-27.

Darwin, P. 2013. Menikmati Gula Tanpa Rasa Takut. Perpustakaan Nasional: Sinar Ilmu.

Elkins, R. 1997. Stevia Nature’s Sweetener. Woodland Publishing, Inc. Pleasant Grove, UT.

Ermawati, D. 2008. Pengaruh Penggunanaan Ekstrak Jeruk Nipis (Citrus aurantifolia) terhadap Residu Nitrat Daging selama Proses Curing. Universitas Sebelas Maret: Surakarta.

Escribano, J., Pedreno, M.A., Garcia-Carmona, F. \& Munoz, R. 1998. Characterization of the antiradical activity of betalains from Beta vulgaris L. Roots. Phytocem. Anal, 9: 124-127.

Evana, Y. 2007. Kajian Pembuatan Sirup Jeruk Nipis (Citrus aurantifolia). Universitas Syiah Kuala: Banda Aceh. 
Jurnal Penelitian Pertanian Terapan

Fardiaz 1998. Mikrobilogi Pangan. Bogor: Departemen Pendidikan dan Kebudayaan Institut Pertanian Bogor Press.

Farikha, I., Anam, C. \& Widowati, E. 2013. . Pengaruh Jenis dan Konsentrasi Penstabil Alami terhadap Karakteristik Fisikokimia Sari Buah Naga Merah (Hylocereus polyrhizus) selama Penyimpanan. Jurnal Teknosains Pangan 2, 1:30-38.

Fitri, E., Harun, N. \& Johan, V, S. 2017. Konsentrasi Gula dan Sari Buah terhadap Kualitas Sirup Belimbing Wuluh (Averrhoa bilimbi L). JOM Faperta UR 4, 1: 1-13.

Geuns, J, M, C. 2003. Stevioside. Phytochemistry, 64: 913-921.

Hanifan, F., Ruhana, A. \& Hidayati, D, Y, N. 2016. Pengaruh Substitusi Sari Umbi Bit (Beta vulgaris L.) terhadap Kadar Kalium, Pigmen Betalain dan Mutu Organoleptik Permen Jeli. Majalah Kesehatan FKUB 2, 1:33-41.

Havlikova, L \& Mikova, K. 1983. Heat Stability of Betacyanins. Lebensm Unters Forsch, 177: 247-250.

Jackman, R, L. \& J, L.S. 1996. Anthocyanins and Betalains. Natural Food Colorants. London: Blackie Academic \& Proffesional.

Jakinovich, W. \& Moon, C. 1990. Evaluation of Plant Extracts for Sweetness Using the Mongolian Gerbil. J Nat Prod 53, 1: 190-195.

Juniaty, D., Ginting, S. \& Karo-Karo, T. 2015. Pengaruh Perbandingan Sari Bit dengan Sari Nenas dan Konsentrasi Gula terhadap Mutu Sirup Bitnas. . J. Rekayasa Pangan dan Pert 3, 3: 1-8.

Kim, I., Yang, M., Lee, O. \& Nam-Suk, K. 2011. The antioxidant activity and the bioactive Compound Content of Stevia rebaudiana water extracts. LWT-Food Sci. Technol, 44: 1328-1332.

Kinghorn, A.D. 2002. Stevia: The Genus Stevia. London: Taylor \& Francis.

Kroyer, G. 2010. Stevioside and Stevia-sweetener in Food: Application, Stability and Interaction with Food Ingredients. Journal of Consumer Protection and Food Safety 5, 2: 225-229.

Lu, G., C, G., Edwards, J, K., D, S, . Mattinson \& Navazio, J. 2003. Biosynthtic Origin of Geosmin in Red Beets (Beta vulgaris L.). J. Agric. Food Chem, 51: 1026-1029.

Mastuti 2010. Identifikasi Pigmen Betasianin pada Beberapa Jenis Inflorescence Celosia. Jurnal Biologi UGM 10, 4: 224-236.

Puslitbangkes 2013. Riset Kesehatan Dasar 2013. Jakarta: Kementrian Kesehatan Republik Indonesia.

Rienoviar \& Nashrianto, H. 2010. Penggunaan Asam Askorbat (Vitamin C) untuk Meningkatkan Daya Simpan Sirup Rosela (Hibiscus sabdariffa Linn). Jurnal Hasil Penelitian Industri 23, 1: 8-18.

Riset Kesehatan Dasar 2010. Badan Penelitian dan Pengembangan Kesehatan. Jakarta: Kementrian Kesehatan RI.

Sarwono, B. 2008. Khasiat dan Manfaat Jeruk Nipis. Jakarta: Agromedia Pustaka.

Soekarno, S.T. 1985. Penilaian Organoleptik untuk Indusri Pangan dan Hasil Pertanian. Jakarta: Bharata Karya Aksara.

Stintzing, F.C. \& Carle, R. 2004. Functional Properties of Anthocyanins and Betalains in Plants, Food and in 
Simarmata, dkk: Komposisi Ekstrak Stevia (Stevia rebaudiana) Terhadap Karakteristik Sirup Bit

Human Nutrition. Trends in Food Science and Technology, 15: 19-38.

Sulastri 2008. Pengaruh Jumlah Santan dan Lama Penyimpanan Beku terhadap Viabilitas Lactobacillus acidophilus dalam Es Krim Nabati Probiotik. Jurnal Teknologi Pangan dan Gizi 2, 6: 1-11.

USDA 2014. Nutritional value of Beets raw.

Wijaya, A. \& Prawira, H. 2002. Pembuatan Sirup Teh Hijau (Green Tea) Rendah Kalori. Institut Pertanian Bogor. Bogor.

Winarno, F.G. 2002. Pangan Gizi, Teknologi dan Konsumen. Jakarta: Gramedia Pustaka Utama.

Yuliana, R., Rahmawati, S.I. \& Novidahlia, N. 2017. Minuman Sirup Limbah Sari Mengkudu (Morinda citrifolia L.). Jurnal Pertanian 8, 2: 122-129. 